\title{
Modeling Potential C, N, H Content in Aboveground Biomass with Spectral Data from
}

\section{Sentinel 2a}

Neftalí Reyes-Zurita ${ }^{1}$, Joaquín A. Rincón-Ramírez ${ }^{2}$, Gerardo Rodríguez-Ortiz ${ }^{1 *}$, José R. Enríquez-del Valle ${ }^{1}$, Vicente A. Velasco-Velasco ${ }^{1}$, Ernesto Castañeda-Hidalgo ${ }^{1}$

${ }^{1}$ Tecnológico Nacional de México, Instituto Tecnológico del Valle de Oaxaca- Division de Estudios de Posgrado e Investigación. Ex Hacienda de Nazareno s/n, Z.C. 71233 Xoxocotlán, Oaxaca, México; ${ }^{2}$ Colegio de Postgraduados, Campus Tabasco, Periférico s/n, Z.C. 86500 H. Cárdenas, México. *Corresponding author (gerardo.rodriguez@ voaxaca.tecnm.mx).

Abstract: Nutrient estimation in forest ecosystems through satellite images allows us to obtain accurate data, starting with data transformation from forest stands and the existing relationship with the spectral information of the image through modeling. The objective of the study was to quantify and validate the content of $\mathrm{C}, \mathrm{N}, \mathrm{H}$ in aboveground tree biomass in managed stands using spatial modeling and satellite images. This study was conducted during 2017-2018 in managed forest stands in San Juan Lachao, Oaxaca, Mexico. Fifteen $400 \mathrm{~m}^{2}$ experimental sites were selectively established, using a completely randomized experimental design of five silvicultural treatments with three replications. As part of data preprocessing, normality and homogeneity of variances assumptions were checked using the Shapiro-Wilk and Bartlett tests, respectively. From the pixels, data of the average of Normalized Difference Vegetation Index (NDVI) that surrounded the sampling sites were contrasted against the data obtained from forest inventory and the regression models to estimate $\mathrm{C}, \mathrm{N}, \mathrm{H}$ and biomass were generated. Models were validated by NDVI. With the models we estimated $0.95 \mathrm{t} \mathrm{ha}^{-1}$ biomass, which contains between 0.61 and 0.63 of $\mathrm{C}, 0.44$ 0.46 of $\mathrm{N}$ and 0.24 of $\mathrm{H}$. The models generated had coefficients of determination $\left(\mathrm{R}^{2}\right)$ of 0.85 to 0.87, which are significant parameters $(p \leq 0.0001)$. These results confirm that the use of Sentinel 
satellite images in the estimation of these elements in forest ecosystems based on the relationship between data inventory and the NDVI is highly reliable.

Keywords: Normalized difference vegetation index; San Juan Lachao; Satelital image.

\section{Introduction}

Sentinel 2A belongs to a program of new satellites developed by the European Union that have been launched since 2015 . As of 2016 the data can be used by any user at an international level. These images have become an indispensable tool for the analysis of flora and fauna. Research has been conducted with this sensor obtaining very satisfactory results due to its high resolution of spatial, temporal, spectral and radiometric data [1]. Therefore, with multitemporal analysis, it is possible to predict and prevent future risk scenarios [2].

In recent years, due to more in-depth understanding of the functional dynamics of both plant physics and physiology, sensor technology has been used to evaluate plants indirectly and nondestructively [3]. Satellite images have an extensive field of use, one of its main applications is related to the possibility of observing changes in the vegetation under study over time [4].

Knowledge of the spectral models of different terrestrial covers permits adequate interpretation of images coming from satellites. When characterizing vegetation, it can be observed that when it is vigorous, it manifests very little energy in the region of the visible spectrum, mainly due to absorption by chlorophyll to carry out photosynthesis, and therefore, a high proportion of the electromagnetic radiation in the near-infrared region is reflected because of the characteristic structure of leaf tissues. The use of satellite images is thus considered a tool for potential quantification the nutrient content in vegetation. However, it is a great challenge to estimate macro and micronutrients in heterogeneous mixed grassland [5].

The Normalized Difference Vegetation Index (NDVI) is a model used in agricultural and forest sites. It shows a direct relationship between the numerical value captured by the sensor and 
the plant variable to be measured, such as plant biomass or vigor. The spectral response of healthy vegetation shows a clear contrast in the visible spectrum, especially the red and the near infrared (NIR) bands. In its interpretation, values below 0.1 are considered to correspond to water bodies and bare soils, while higher values are indicators of the photosynthetic activity of different types of vegetation [6]. This index was introduced with the objective of separating vegetation from the brightness produced by the soil. It is based on the peculiar radiometric behavior of vegetation, related to the photosynthetic activity and the plant's leaf structure, which determine plant vigor [7].

In Mexico [8], Italy [9], Philippines [10], China [11], France [12] and other countries, work has been done with the same satellite (NDVI) for analysis of urban vegetation, for soil classification, for crop analysis, etc. Direct models center the data at a single point, while satellite images (with correct processing of the image and dates as close as possible to the sampling dates) have shown to improve the accuracy of forest biomass estimations [13].

Although it has been relegated due to the methodological difficulties involved when aiming to produce detailed cartographic representation of vegetation variability or to provide relevant information for forest management and decision-making at landscape scale [10], transformation of the data recorded at the site (diameter at breast height and total height) and the relationship between the data and the pixels provide the information needed for modeling the strata of a given forest in terms of silviculture and ecology. In addition, with the satellite data, it is possible to estimate tree height and update inventory or fill in nonexistent data effectively through correlation of pixel data and points recorded in the stand inventory. Moreover, LIDAR measurements provide samples of the forest structure that must be integrated with satellite images to predict and map the variations of forest structure at the landscape scale [14].

Aboveground biomass is a fundamental element of forest ecosystems, very important for its capacity to store $\mathrm{C}$ as well as other elements such as $\mathrm{N}$ and $\mathrm{H}$, which indicates the forest's 
production capacity. Forest ecosystems store very significant amounts of gases with greenhouse effect [15]. Estimation of forest stand biomass with accurate data from remote sensors is based on a strong statistical relationship between $\mathrm{C}$ and the spectral response captured by the sensor as spatially explicit knowledge [16].

Through research, it has been shown that forest reflectivity is assessed through the vertical distribution of the tree strata [17]. Interactions between the structural variables of the inventory data such as height, basal area, density, age and biomass at the time of modeling with satellite images have also been detected [18].

Planning forestry activities requires information such as geographical features. In addition to thematic maps that support decision-making, new alternatives have been adopted, as is the case in northwestern Mexico where Landsat ETM satellite images from 2001 were used to optimize forestry planning [19].

The community San Juan Lachao has large forest areas that are geographically difficult to access. This community is a pioneer in the commercialization of $\mathrm{C}$ bonds (Carboin) in the international voluntary market, through development of the project under the forest protocol for Mexico of the Climate Action Reserve. The community are interested in constantly improving their methods of evaluating their natural resources. In this context, the use of Sentinel satellite images presents an alternative that saves time and resources in evaluating natural and environmental resources. For this reason, the objective of this study was to quantify and validate the $\mathrm{C}, \mathrm{N}$ and $\mathrm{H}$ content in aboveground tree biomass in different silvicultural treatments using spatial modeling and satellite images. 


\section{Material and Methods}

\subsection{Study Area}

The present research was carried out during 2017-2018 in the timber harvesting stands of San Juan Lachao, Oaxaca, in southern Mexico. The stands are located at an average altitude of $1885 \mathrm{~m}$ on slopes between $20-40 \%$. Geographically, they are located between the coordinates: $16^{\circ} 12^{\prime}$ 42.66" $\mathrm{N}$ and $97^{\circ} 05^{\prime} 50.46^{\prime \prime} \mathrm{W}$. Predominant climate is warm subhumid with average annual temperature of $22{ }^{\circ} \mathrm{C}$; precipitation is abundant between May and September and averages 2,500 mm per year.

\subsection{Experimental Sites}

Fifteen experimental units of $400 \mathrm{~m}^{2}$ were selectively established in 2017 , using a completely randomized experimental design in five silvicultural treatments and three repetitions. The sites were located spatially with a GPS (global positioning system) (Garmin Trex 30, USA). A forestry tree inventory was carried out, obtaining the following variables: diameter at breast height (DBH, $\mathrm{cm}$ ) and total height (TH, m), both measured with a diametric tape (Jackson, MS 800-647-5368) and clinometer (PM-5 360 PC).

\subsection{Nutrients in Aboveground Biomass}

In the arboreal compartment, the total tree volume of the pines and broadleaf species was calculated with the Schumacher-Hall model (allometric) [20] (Eq 1).

$$
v_{(s t)}=\beta_{0} \times D B H^{\beta_{1}} \times T H^{\beta_{2}}+\beta_{3}(D B H)^{2} \quad \ldots \ldots \ldots \text { Eq. } 1
$$

Where: $v_{(s t)}=$ stem total volumen outside bark $\left(\mathrm{m}^{3}\right), D B H=$ diameter at breast height $(\mathrm{cm}), T H=$ total height $(\mathrm{m}), \beta_{i}=$ regression coefficient.

To estimate the biomass of the different tree parts, a sample of approximately $100 \mathrm{~g}$ was extracted from each part and kept in a tagged paper bag to determine fresh weight $(\mathrm{FW}, \mathrm{kg})$ and dry weight (DW, kg) after drying for six days at temperature between $75^{\circ} \mathrm{C}$ and $100{ }^{\circ} \mathrm{C}$. The total 
biomass of each component was obtained by conversion factors (DW/FW), using the ChávezPascual [21] methodology. Laboratory analyses were performed in order to obtain the nutrient content in plant samples with an elemental organic analyzer PE 2400, series II (Eq 2).

$$
n_{i}=\left(\frac{n c}{100}\right) B \ldots \ldots \ldots \text { Eq. } 2
$$

Where: $n_{i}=$ nutrient $(\mathrm{kg}), n c=$ nutrient content $(\%), B=$ biomass $(\mathrm{kg})$.

2.4 Spectral data Sentinel 2A

The multispectral image was obtained from the Sentinel Scientific Data Hub web site. The sensor manages 13 bands in the visible spectrum (Table 1).

Table 1. Technical characteristics of Sentinel 2A.

\begin{tabular}{lccc}
\hline & \multicolumn{3}{c}{ Pixel } \\
Sensor & Wavelength $(\mu \mathrm{m})$ & $(\mathrm{m})$ & Band size $(\mathrm{m})$ \\
\hline Band 2 & 490 & 10 & $2-10$ \\
Band 3 & 560 & 10 & $2-10$ \\
Band 4 & 665 & 10 & $2-10$ \\
Band 8 & 842 & 10 & $2-10$ \\
Band 5 & 705 & 20 & $2-20$ \\
Band 6 & 740 & 20 & $2-20$ \\
Band 7 & 783 & 20 & $2-20$ \\
Band 8a & 865 & 20 & $2-20$ \\
Band 11 & 1610 & 20 & $2-20$ \\
Band 12 & 2190 & 20 & 20 \\
Band 1 & 433 & & 20
\end{tabular}




\begin{tabular}{llll}
\hline Band 9 & 940 & 60 & $2-60$ \\
Band 10 & 1375 & 60 & $2-60$ \\
\hline
\end{tabular}

Thirteen bands were processed using QGIS 2.18.17® software. First, as part of preprocessing, atmospheric and geometric corrections were made, and then the NDVI was calculated (Eq 3). Two satellite bands were chosen: bands 4 and 8 with 10 m of spatial resolution. Finally, in each georeferenced sampling site, the average of the surrounding pixels was obtained using a 9×9 window, where the central pixel corresponded to the inventoried site; with this average, the correlation between pixels and elements such as $\mathrm{C}, \mathrm{N}, \mathrm{H}$ and biomass was made.

$$
N D V I=\frac{N I R-R}{N I R+R}
$$

Where: $N D V I=$ normalized difference vegetation index, $N I R=$ near infrared, $R=$ red.

The indexes were constructed in order to highlight some characteristics of the vegetation, which is mainly a function of the chlorophyll, cell structure and water content of the vegetation [22]. The indexes are more sensitive in some parts of the electromagnetic spectrum and better detected in specific bands [23].

\subsection{Data Analysis}

A database was integrated with which regression models per tree were tested. The dependent variable was the value of the pixels and the independent variables were $\mathrm{C}, \mathrm{H}, \mathrm{N}$ and biomass (Table 1). The analyses were carried out with SAS [24] statistical software. Assumptions of normality and homogeneity of variances were verified with the Shapiro-Wilk (UNIVARIATE procedure) and Bartlett tests, respectively. The models were adjusted using the MODEL procedure and selected based on their statistical indicators. A simple linear model was used for $\mathrm{C}, \mathrm{N}$ and biomass and exponential regression for $\mathrm{H}$. 


\section{Results}

The models that best estimated C, N, H and biomass from spectral data were the simple linear and the exponential regression models. The root of mean square error (RMSE) showed low values, between 0.01 and 0.02 , indicative of good fit. The NDVI spectral data explained $85 \%$ of the variation in $\mathrm{C}, \mathrm{H}$ and biomass and $87 \%$ of the variation in $\mathrm{N}$; in all cases, variation was significant $(p=0.0001)$. In this way, the parameters $\left(\beta_{0}\right.$ and $\left.\beta_{1}\right)$ integrated to estimate the nutrient contents and biomass were essential in the models $(p=0.0001)$.

The NDVI based on the reflectivity of the Sentinel 4 and 8 bands were those that satisfactorily described the elements' behavior due to the strong energy absorption caused by the vigorous healthy vegetation, chlorophyll absorption and moisture present in the vegetation (Table 2).

Table 2. Regression models for nutrients and biomass.

\begin{tabular}{|c|c|c|c|c|c|}
\hline & & Standar & & Prob > & \\
\hline Equation/variable Parameter & Estimate & Error & t-value & $|t|$ & \\
\hline$C=\beta_{0}(N D V I)+\beta_{1} \cdot \mathrm{R}_{\text {adj }}^{2}=0.85$ & & & & & 0.0294 \\
\hline Intercept & 0.00137 & 0.00018 & 7.39 & 0.0001 & \\
\hline NDVI & 0.70322 & 0.01184 & 59.42 & 0.0001 & \\
\hline$N=\beta_{0}(N D V I)+\beta_{1} \cdot \mathrm{R}_{\text {adj }}^{2}=0.87$ & & & & & 0.0277 \\
\hline Intercept & 0.1989 & 0.02514 & 7.91 & 0.0001 & \\
\hline NDVI & 0.70762 & 0.1075 & 65.82 & 0.0001 & \\
\hline$H=\beta_{0} e^{\beta 1}(N D V I) \cdot \mathrm{R}_{\text {adj }}^{2}=0.85$ & & & & & 0.0172 \\
\hline Intercept & 0.0132 & 0.00167 & 0.0096 & 0.0001 & \\
\hline NDVI & 0.7043 & 0.011 & 0.6787 & 0.0001 & \\
\hline
\end{tabular}


$B=\beta_{0}(N D V I)+\beta_{1} \cdot \mathrm{R}^{2}{ }_{\text {ddj }}=0.85$

\begin{tabular}{llllll}
\hline Intercept & $\beta_{0}$ & 0.0006 & 0.00007 & 7.42 & 0.0001 \\
\hline NDVI & $\beta_{1}$ & 0.7029 & 0.01182 & 59.47 & 0.0001
\end{tabular}

$\mathrm{C}, \mathrm{N}, \mathrm{H}, \mathrm{B}=$ carbón, nitrogen, hydrogen and biomass $(\mathrm{kg}), \beta_{0,1,2,3}=$ regression parameters, NDVI $=$ normalized difference vegetation index; $\mathrm{RMSE}=$ root mean square of error; $\mathbf{R}^{2}{ }_{\text {adj }}=$ adjusted coefficient of determination.

The modeled $\mathrm{C}$ storage potential of the stands with silvicultural treatment was $0.63 \mathrm{tha}^{-1}$ in the high areas where pine-oak is the predominant vegetation. In the stands intervened in the last two years growing in wet climate, modeled potential $\mathrm{C}$ storage was $0.61 \mathrm{t} \mathrm{C} \mathrm{ha}^{-1}$, due to the variation in silvicultural treatments and the type of dominant vegetation and climate. $\mathrm{N}$ is the second most important element in the forest under study, which generates values between $0.44 \mathrm{t}$ $\mathrm{ha}^{-1}$ and $0.46 \mathrm{t} \mathrm{ha}^{-1}$. These values are high compared with the other evaluated nutrients. This variability may be because the silvicultural regimes were applied in different periods (2012 to 2015) (Figure 1).

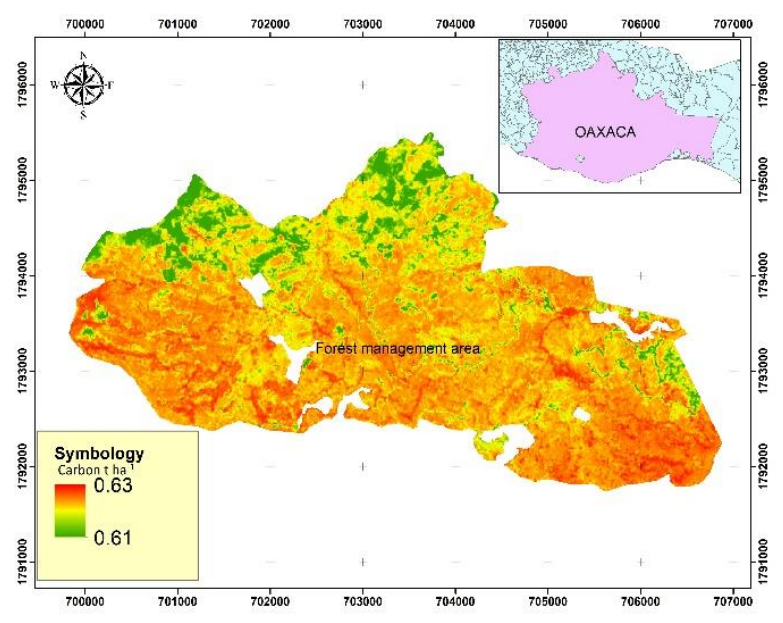

A

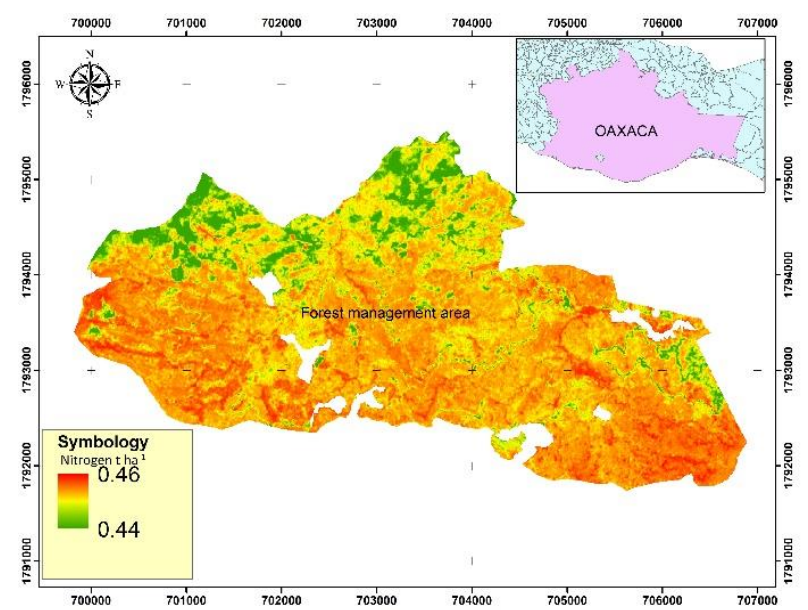

B

Figure 1. Carbon (A) and nitrogen (B) expansion in the forest management sites. 
Hydrogen is one of the scarcest elements, found in small proportions in the forest. The model result obtained in the managed stands was $0.22 \mathrm{t} \mathrm{H} \mathrm{ha}^{-1}$ to $0.24 \mathrm{t} \mathrm{H} \mathrm{ha}^{-1}$.

Biomass expansion was similar obtaining between $0.93 \mathrm{t} \mathrm{ha}^{-1}$ and $0.95 \mathrm{t} \mathrm{ha}^{-1}$. The areas with the least amount of biomass are stands that were intervened in 2015 and where oak-pine vegetation predominates (Figure 2).
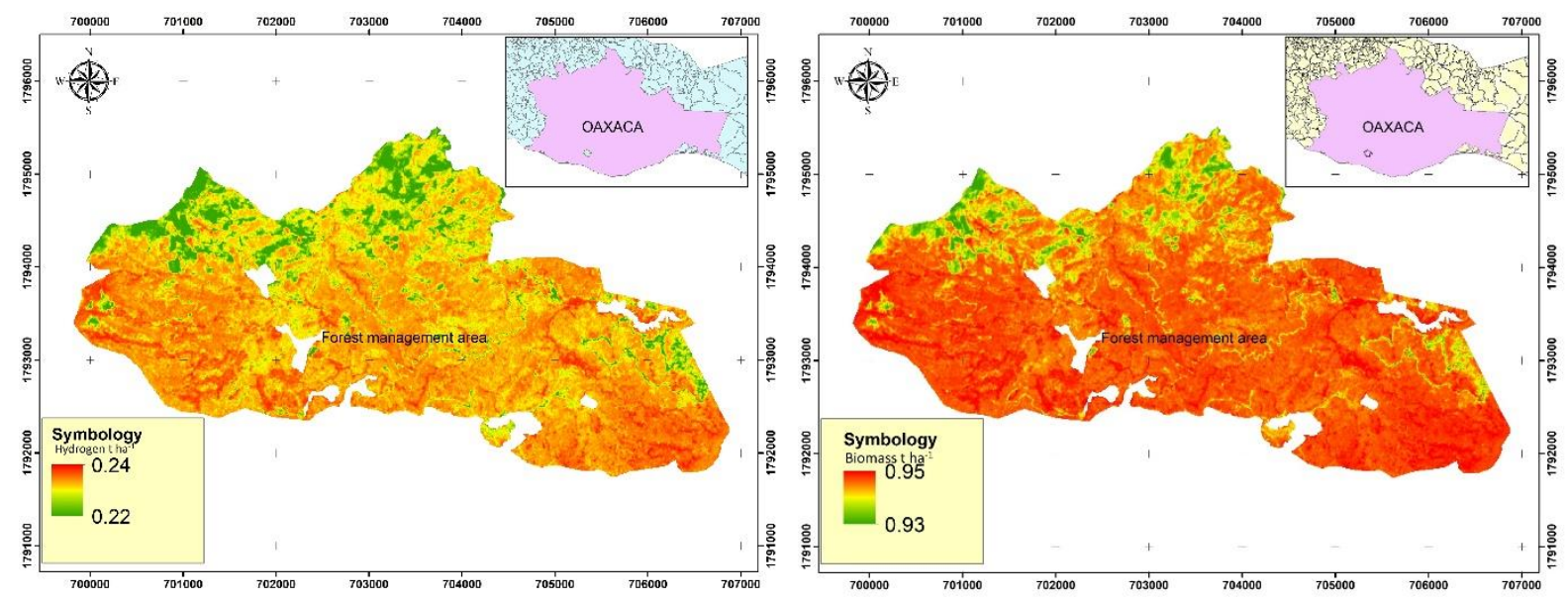

Figure 2. Hydrogen (A) and aboveground biomass (B) expansion at area under forest management.

\section{Discussion}

The need to know and simulate the different behaviors associated with the different vegetation changes has been increasing. One of the first processes is observation; then comes experimentation, and finally satellite images $[25,26]$ to obtain geolocated information, especially in large areas of difficult access [27]. To make the most accurate $\mathrm{C}$ estimation, the spatial resolution of the satellite image becomes a key factor in validating models. A study done by Yan [28] working with resolutions between 30 and $1000 \mathrm{~m}^{2}$, used a model that showed high coefficients of variation as the image resolution decreased. The results of our investigation was $5.55(\mathrm{CV})$ with a $20 \times 20 \mathrm{~m}$ resolution, the difference due to the type of satellite used (Sentinel 2a). 
Results of studies carried out in Mexico, the United States, Europe, Iran and Asia, with different satellites such as Sentinel 2 and 3, Landsat and Envisat, using statistical models, have similar coefficients of determination, when compared with the results obtained in our research. This highlights the fact that Sentinel sensors present differences relative to others, that is, it is much better to make these types of estimates in forest ecosystems (Table 3).

Table 3. Use of different sensors in the $\mathrm{C}, \mathrm{N}, \mathrm{H}$ and biomass estimation.

\begin{tabular}{|c|c|c|c|c|c|c|}
\hline Country & Ecosystem & Variable & Sensor & Index & Model & $\mathrm{R}^{2}$ \\
\hline Mexico & Pine forest [2] & $\begin{array}{l}\text { Biomass } \\
\text { and carbon }\end{array}$ & Landsat & NDVI & $\begin{array}{l}\text { Multiple linear } \\
\text { regression }\end{array}$ & 0.67 \\
\hline USA & $\begin{array}{l}\text { Mixed forest } \\
{[29]}\end{array}$ & $\begin{array}{l}\text { Biomass } \\
\text { and carbon }\end{array}$ & Landsat 7 & NDVI & Multiple regression & $\begin{array}{l}0.67 \\
0.82\end{array}$ \\
\hline $\begin{array}{l}\text { USA, } \\
\text { Europe, }\end{array}$ & $\begin{array}{l}\text { Mixed forest } \\
{[30]}\end{array}$ & Carbon & Envisat & & Linear regression & $\begin{array}{l}0.70, \\
0.90\end{array}$ \\
\hline Asia & & & & & & \\
\hline Iran & $\begin{array}{l}\text { Mixed forest } \\
{[31]}\end{array}$ & Biomass & Sentinel-2A & NDVI & Nonlinear regression & $\begin{array}{l}0.70, \\
0.95\end{array}$ \\
\hline USA & $\begin{array}{l}\text { Crop and grass } \\
{[32]}\end{array}$ & Nitrogen & $\begin{array}{l}\text { Sentinel-2 } \\
\text { and } 3\end{array}$ & MTCI & Linear regression & 0.78 \\
\hline Europ & $\begin{array}{l}\text { Deciduous } \\
\text { forest [33] }\end{array}$ & Biomass & Sentinel-2 & NDVI & $\begin{array}{l}\text { Regression with } \\
\text { variable selection }\end{array}$ & 0.70 \\
\hline
\end{tabular}

MTCI = MERIS Terrestrial Chlorophyll Index, NDVI = normalized difference vegetation index. 
The models generated from Sentinel 2a images for $\mathrm{C}$ estimation presented an $\mathrm{R}^{2}=0.85$, which is similar to research work carried out in southern Sweden with MODIS satellite images that obtained 0.76 and $0.85 \mathrm{tha}^{-1}$ in the $\mathrm{CO}_{2}$ with NDVI estimation $[34,35]$.

Indirect estimation of $\mathrm{C}$ and forest variability is done with different methods and technologies [36] from different variables, either height $[37,38]$ or biomass, which was the methodology used in our investigation.

In estimating $\mathrm{N}$ with NDVI, it has been shown that reflectivity in some parts of the electromagnetic spectrum is highly correlated with the $\mathrm{N}$ percentage measured in the stand at tree level $[39,40]$. In our research it produced an $\mathrm{R}^{2}=0.87$, comparable with the results of Pellissier [41] and Wang [42] in mixed temperate forest. Comparing the results generated in agricultural areas with airborne hyperspectral images, we had an adjustment of $\mathrm{R}^{2}=0.79$, suggesting that the Sentinel 2a images estimate nutrient contents much better. Moreover, comparing the results obtained by Ewald [43] with the Lidar data $\left(\mathrm{R}^{2}=0.63\right)$, with the images obtained from Sentinel, more robust models can be generated to predict the aforementioned variables.

For this reason, the use of remote sensing in nutrient quantification and also in forest management to estimate forest productivity in large areas to support establishing inventory control points has boomed [44]. The result obtained in $\mathrm{H}$ quantification was $0.22 \mathrm{t} \mathrm{ha}^{-1}$, through pixel ratio, to $0.24 \mathrm{t} \mathrm{ha}^{-1}$, obtained from the samples collected in the stand. Norverto [45] mentions that $\mathrm{H}$ is one of the scarcest elements; in a complete tree $6 \%$ can be found, depending on the species.

The different satellite images provide very accurate information at the local, regional and national level if their methodology is followed correctly [28]. The biomass estimated through the NDVI and simple regression was $0.95 \mathrm{t} \mathrm{ha}^{-1}$ with an $\mathrm{R}^{2}=0.85$, values slightly lower than those obtained by Lumbierres [46] using MODIS images from NDVI (1 to $\left.10 \mathrm{t} \mathrm{ha}^{-1}\right)$. 
This difference could be due, first, to the fact that the MODIS sensor spatial resolution is lower than that of Sentinel and, second, to its smaller $\mathrm{R}^{2}=0.62$ with multiple regression. It may also vary depending on vegetation type and the site condition. For example, Ruiz [47] obtained an $\mathrm{R}^{2}=0.89$ in Pinus halepensis Mill, while Méndez [48], who used the ALOS-PALSAR sensor found $\mathrm{R}^{2}=0.63$ in pine species, and Cáceres [49] in an analysis of temporal behavior of grass biomass in Honduras obtained an $\mathrm{R}^{2}=0.82$ from the biomass and the spectral index (SAVI) ratio with simple linear regression using Sentinel $2^{\mathrm{a}}$ images. However, in the biomass quantification of managed forest areas of this study, a coefficient of $\mathrm{R}^{2}=0.85$ was obtained (Table 1 ). Comparing the results with Vaglio [33] of $\mathrm{R}^{2}$ from 0.70 to 0.75 (Table 2) demonstrates that this satellite is a better biomass predictor.

\section{Conclusions}

Estimates carried out using statistical models with spectral data in an area of stands managed under silvicultural regimes at San Juan Lachao in southern Mexico, showed similar levels of C $\left(0.63 \mathrm{t} \mathrm{ha}^{-1}\right)$, while nitrogen was $0.46 \mathrm{t} \mathrm{ha}^{-1}$ on average. Hydrogen was lower than $0.24 \mathrm{t} \mathrm{ha}^{-1}$, being one of the scarcest elements. Both the regression models and their parameters $\left(\beta_{0}\right.$ and $\left.\beta_{1}\right)$ showed significant estimates $(p=0.0001)$ of the nutrients and biomass because the images used have a resolution of 10, 20 and $60 \mathrm{~m}$, which is a key point in selecting the sensor. Spatial modeling of aboveground tree biomass and nutrients with Sentinel 2a images is reliable for use in stands under silvicultural regimes.

Supplementary Materials: Excel® data base of contents of biomass, C, N and H.

Acknowledgments: We would like to acknowledge the Community of San Juan Lachao and Conacyt for funding the scholarship for the first author.

Author Contributions: G.R-O. and J.A. R-R conceived the research design, conducted the field data collection, analysis, and wrote the manuscript. N. R-Z. was a co-principal author, assisted in 
the field data collection, analyzed the data and wrote the manuscript. J.R. E-V. and V.A. V-V assisted in analysis of the results and wrote the manuscript. And E. C-H. revised the manuscript.

Conflicts of Interest: The authors declare no conflict of interest.

\section{References}

1. Muñoz, R. C. A.; Treviño, G. E. J.; Verástegui, C J.; Jiménez, P. J.; Aguirre, C. O. A. Desarrollo de un modelo espacial para la evaluación del peligro de incendios forestales en la Sierra Madre Oriental de México. Investigaciones Geográficas 2005, 56, 101-117.

2. Martínez, B. R. A.; Aguirre, C. O. A.; Vargas, L. B.; Jiménez, J,; Treviño, G. E. J.; Yerena, Y. J. I. Modelación de biomasa y carbono arbóreo aéreo en bosques del estado de Durango. Revista Mexicana de Ciencias Forestales 2016, 7(35), 91-106.

3. Porras, A. G. Potencialidad y nuevas orientaciones en el uso de la teledetección en agricultura y selvicultura. Ambienta 2013, 105, 6-15.

4. Baccini, A.; Friedl, M. A.; Woodcock, C. E.; Warbington, R. Forest biomass estimation over regional scales using multisource data. Geophysical Research Letters 2004, 31(10), 2-5. https://doi.org/10.1029/2004GL019782

5. Paruelo, J. M. La caracterización funcional de ecosistemas mediante sensores remotos. Ecosistemas 2008, 17(3), 4-22.

6. Meneses-Tovar, C. L. El índice normalizado diferencial de la vegetación como indicador de la degradacion de los bosques. Unasylva 2011, 62(238), 39-46.

7. Peña-Barragán, J. M.; Ngugi, M. K.; Plant, R. E.; Six, J. Object-based crop identification using multiple vegetation indices, textural features and crop phenology. Remote Sensing of Environment 2011, 115(6), 1301-1316. https://doi.org/10.1016/j.rse.2011.01.009

8. Sowter, A.; Bin, C.A. M.; Cigna, F.; Marsh, S.; Athab, A.; Alshammari, L. Mexico City land subsidence in 2014-2015 with Sentinel-1 IW TOPS: Results using the Intermittent SBAS 
(ISBAS) technique. International Journal of Applied Earth Observation and Geoinformation 2016, 52, 230-242. https://doi.org/10.1016/j.jag.2016.06.015

9. Pulvirenti, L.; Squicciarino, G.; Cenci, L.; Boni, G.; Pierdicca, N.; Chini, M.; ... Campanella, P. A surface soil moisture mapping service at national (Italian) scale based on Sentinel-1 data. Environmental Modelling and Software 2018, 102, 13-28. https://doi.org/10.1016/j.envsoft.2017.12.022

10. Castillo, J. A. A.; Apan, A. A.; Maraseni, T. N.; Salmo, S. G. Estimation and mapping of above-ground biomass of mangrove forests and their replacement land uses in the Philippines using Sentinel imagery. ISPRS Journal of Photogrammetry and Remote Sensing 2017, 134, 70-85. https://doi.org/10.1016/j.isprsjprs.2017.10.016

11. Li, F.; Song, G.; Liujun, Z.; Yanan, Z.; Di, L. Urban vegetation phenology analysis using high spatio-temporal NDVI time series. Urban Forestry and Urban Greening 2017, 25, 43-57. https://doi.org/10.1016/j.ufug.2017.05.001

12. Veloso, A.; Mermoz, S.; Bouvet, A.; Le-Toan, T.; Planells, M.; Dejoux, J.F.; Ceschia, E. Understanding the temporal behavior of crops using Sentinel-1 and Sentinel-2-like data for agricultural applications. Remote Sensing of Environment 2017, 199, 415-426. https://doi.org/10.1016/J.RSE.2017.07.015

13. Gómez, C.; White, J. C.; Wulder, M. A.; Alejandro, P. Historical forest biomass dynamics modelled with Landsat spectral trajectories. ISPRS Journal of Photogrammetry and Remote Sensing 2014, 93, 14-28. https://doi.org/10.1016/j.isprsjprs.2014.03.008

14. Cigna, F.; Sowter, A. The relationship between intermittent coherence and precision of ISBAS InSAR ground motion velocities: ERS-1/2 case studies in the UK. Remote Sensing of Environment 2017, 202, 177-198. https://doi.org/10.1016/j.rse.2017.05.016

15. Vega-Araya, M.; Bonatti-González, J. Monitoreo forestal con sensoramiento remoto en el 
marco del cambio climático Forest Monitoring with Remote Sensing Within the Framework of Climate Change. Revista UniveRsidad en Diálogo 2016, 6(2), 59-73. https://doi.org/10.15359/udre.6-2.4

16. Lees, K. J.; Quaife, T.; Artz, R. R. E.; Khomik, M.; Clark, J. M. Potential for using remote sensing to estimate carbon fluxes across northern peatlands - A review. Science of the Total Environment 2018, 615, 857-874. https://doi.org/10.1016/j.scitotenv.2017.09.103

17. Wang, Q.; Li, P. Canopy vertical heterogeneity plays a critical role in reflectance simulation. Agricultural and Forest Meteorology 2013, 169, 111-121. https://doi.org/10.1016/j.agrformet.2012.10.004

18. Palestina, R. A.; Equihua, M.; Pérez-Maqueo, O. M. Influencia de la complejidad estructural del dosel en la reflectancia de datos Landsat TM. Madera y Bosques 2015, 21(1), 63-75.

19. Ancira-Sánchez, L.; Treviño-Garza, J. E. Using satellite images for forest management in northeast Mexico. Madera y Bosques 2015, 21(1), 77-91.

20. Corral, R. J. J.; Vargas, L. B. Sistema biométrico para la planeación del manejo forestal sustentable de los ecosistemas con potencial maderable en México (2013-C01-209772). Oaxaca, México, 2013.

21. Chávez-Pascual, E. Y.; Rodríguez-Ortiz, G.; Enríquez-del Valle, J. R.; Velasco-Velasco, V. A.; Gómez-Cárdenas, M. Compartimentos de biomasa aérea en rodales de Pinus oaxacana bajo tratamientos silvícolas. Madera y Bosques 2017, 23(3), 147-161. doi:10.21829/myb.2017.2331627

22. Soria, R. J.; Granados, R. R. Relación entre los índices de vegetación obtenidos de los sensores AVHRR del satélite NOAA y TM del Landsat. Ciencia Ergo Sum 2005, 12(2), 167-174.

23. Cohen, W. B.; Goward, S. N. Landsat's role in ecological applications of remote sensing. Biosciencie 2004, 54(6), 535-545. 
24. SAS Institute Inc. SAS/ETS 9.3 User's Guide. SAS Institute, Cary, NC. USA, 2011.

25. Alton, P. B. Decadal trends in photosynthetic capacity and leaf area index inferred from satellite remote sensing for global vegetation types. Agricultural and Forest Meteorology 2018, 250-251, 361-375. https://doi.org/10.1016/j.agrformet.2017.11.020

26. Huesca, M.; García, M.; Roth, K. L.; Casas, A.; Ustin, S. L. Canopy structural attributes derived from AVIRIS imaging spectroscopy data in a mixed broadleaf/conifer forest. Remote Sensing of Environment 2016, 182, 208-226. https://doi.org/10.1016/j.rse.2016.04.020

27. Sastre, L. F. S.; Marcos-Robles, J. L.; Llorente, E. H.; Navarro, S. H.; Prieto, P. C. Aplicación de tecnologías de teledetección al estudio de biomasa forestal. Revista Iberica de Sistemas y Tecnologias de Información 2016, 19, 61-76. https://doi.org/10.17013/risti.19.61-76

28. Yan, E.; Lin, H.; Wang, G.; Sun, H. Multi-resolution mapping and accuracy assessment of forest carbon density by combining image and plot data from a nested and clustering sampling design. Remote Sensing 2016, 8(7), 571. https://doi.org/10.3390/rs8070571

29. Zheng, D.; Rademacher, J.; Chen, J.; Crow, T.; Bresee, M.; Le Moine, J.; Ryu, S. R. Estimating aboveground biomass using Landsat 7 ETM+ data across a managed landscape in northern Wisconsin, USA. Remote Sensing of Environment 2004, 93(3), 402-411. https://doi.org/10.1016/j.rse.2004.08.008

30. Thurner, M.; Beer, C.; Santoro, M.; Carvalhais, N.; Wutzler, T.; Schepaschenko, D.; ... Schmullius, C. Carbon stock and density of northern boreal and temperate forests. Global Ecology and Biogeography 2014, 23(3), 297-310. https://doi.org/10.1111/geb.12125

31. Vafaei, S.; Soosani, J.; Adeli, K.; Fadaei, H.; Naghavi, H.; Pham, T. D.; Bui, D. T. Improving accuracy estimation of Forest Aboveground Biomass based on incorporation of ALOS-2 PALSAR-2 and Sentinel-2A imagery and machine learning: A case study of the Hyrcanian forest area (Iran). Remote Sensing 2018, 10(2), 172. https://doi.org/10.3390/rs10020172 
32. Clevers, J.G.P.W.; Gitelson, A.A. Remote estimation of crop and grass chlorophyll and nitrogen content using red-edge bands on Sentinel-2 and -3. International Journal of Applied Earth Observation and Geoinformation 2013, 23, 344-351. http://dx.doi.org/10.1016/j.jag.2012.10.008

33. Vaglio, L. G.; Balling, J.; Corona, P.; Mattioli, W.; Papale, D.; Puletti, P.; Rizzo, M.; Truckenbrodt, J. Y.; Urban, M. Above-ground biomass prediction by Sentinel-1 multitemporal data in central Italy with integration of ALOS2 and Sentinel-2 data. J. Appl. Remote Sens. 2018, 12(1), 1-19 doi: 10.1117/1.JRS.12.016008.

34. Schubert, P.; Eklundh, L.; Lund, M.; Nilsson, M. Estimating northern peatland $\mathrm{CO}_{2}$ exchange from MODIS time series data. Remote Sensing of Environment 2010, 114(6), 1178-1189. https://doi.org/10.1016/j.rse.2010.01.005

35. Liu, N.; Harper, R. J.; Handcock, R. N.; Evans, B.; Sochacki, S. J.; Dell, B.; ... Liu, S. Seasonal timing for estimating carbon mitigation in revegetation of abandoned agricultural land with high spatial resolution remote sensing. Remote Sensing 2017, 9(6), 545. https://doi.org/10.3390/rs9060545\}

36. Jiang, Q.; Chen, Y.; Guo, L.; Fei, T.; Qi, K. Estimating soil organic carbon of cropland soil at different levels of soil moisture using VIS-NIR spectroscopy. Remote Sensing 2016, 8(9), 755. https://doi.org/10.3390/rs8090755

37. Nunes, M. H.; Ewers, R. M.; Turner, E. C.; Coomes, D. A. Mapping aboveground carbon in oil palm plantations using LiDAR: A comparison of tree-centric versus area-based approaches. Remote Sensing 2017, 9(8), 1-13. https://doi.org/10.3390/rs9080816

38. Solberg, S.; May, J.; Bogren, W.; Breidenbach, J.; Torp, T.; Gizachew, B. Interferometric SAR DEMs for forest change in Uganda 2000-2012. Remote Sensing 2018, 10(2, 228. https://doi.org/10.3390/rs10020228 
39. García, M. A.; Pérez, C. F.; de la Riva, F. J. Evaluación de los recursos de biomasa residual forestal mediante imágenes del satélite Landsat y Sig. GeoFocus 2006, 6, 205-230.

40. Lepine, L. C.; Ollinger, S. V.; Ouimette, A. P.; Martin, M. E. Examining spectral reflectance features related to foliar nitrogen in forests: Implications for broad-scale nitrogen mapping. Remote Sensing of Environment 2016, 173, 174-186. https://doi.org/10.1016/j.rse.2015.11.028

41. Pellissier, P. A.; Ollinger, S. V.; Lepine, L. C.; Palace, M. W.; McDowell, W. H. Remote sensing of foliar nitrogen in cultivated grasslands of human dominated landscapes. Remote Sensing of Environment 2015, 167, 88-97. https://doi.org/10.1016/j.rse.2015.06.009

42. Wang, Z.; Wang, T.; Darvishzadeh, R.; Skidmore, A. K.; Jones, S.; Suarez, L.; ... Hearne, J. Vegetation indices for mapping canopy foliar nitrogen in a mixed temperate forest. Remote Sensing 2016, 8(6), 1-20. https://doi.org/10.3390/rs8060491

43. Ewald, M.; Aerts, R.; Lenoir, J.; Fassnacht, F. E.; Nicolas, M.; Skowronek, S.,; ... Schmidtlein, S. LiDAR derived forest structure data improves predictions of canopy $\mathrm{N}$ and $\mathrm{P}$ concentrations from imaging spectroscopy. Remote Sensing of Environment 2018, 211, 13-25. https://doi.org/10.1016/j.rse.2018.03.038

44. Smith, M. L.; Ollinger, S. V.; Martin, M. E.; Aber, J. D.; Hallett, R. A.; Goodale, C. L. Direct Estimation of Aboveground Forest Productivity through Hyperspectral Remote Sensing of Canopy Nitrogen. Ecological Applications 2013, 12(5), 1286-1302.

45. Norverto, A. C. La fijación de $\mathrm{CO}_{2}$ en plantaciones forestales y en productos de maderas en Argentina. Proyecto Forestal de Desarrollo Secretaria de Agricultura, Ganadería, Pesca y Alimentos 2013, 1-13.

46. Lumbierres, M.; Méndez, P.; Bustamante, J.; Soriguer, R.; Santamaría, L. Modeling Biomass Production in Seasonal Wetlands Using MODIS NDVI Land Surface Phenology. Remote 
Sensing 2017, 9(4), 392. https://doi.org/10.3390/rs9040392

47. Ruiz, D. D.; Gracia, T. L.; Gracia, A. L. M.; Fernández, J. de la R. Estimación de la pérdida de biomasa y de las emisiones de $\mathrm{CO}_{2}$ generadas por la combustión de masas forestales de Pinus halepensis Mill. en el incendio de Luna (Aragón), mediante datos LiDAR-PNOA. XVII Congreso Nacional de Tecnologías de Información Geográfica, España 2016, 83-88.

48. Méndez, E.; Valés, J. J.; Pino, I.; Granado, L.; Montoya, G.; Prieto, R.; ... Suárez, J. Determinación de biomasa forestal mediante la utilización de técnicas de teledetección con imágenes radar. Estudio piloto en ámbito de la provincia de Huelva. Revista de Teledeteccion 2016, 45, 71-86. https://doi.org/10.4995/raet.2016.3984\}

49. Cáceres, J. D. Análisis del comportamiento temporal de la biomasa en pastos del Departamento de Olancho en el contexto del cambio global - Fase II. Revista de Ciencias Espaciales 2013, $7(1), 97-114$. 